\title{
THE DISTRIBUTION, IMPORTANCE, BIOLOGY AND CONTROL, OF CHROMOLAENA ODORATA (L.) K.\& R.A MAJOR WEED SPECIES OF COCONUT PLANTATION IN SRI LANKA
}

\author{
By \\ T.G.L.G. Gunasekara ${ }^{1}$
}

\begin{abstract}
Chromolaena odorata (1.) K. \& R. is a tropical perennial weed species qf the Asteraceae family that has become a serious problem in coconut plantations in Sri Lanka and in the tropics of Asia and Africa. The history of distribution, habitat and economic importance is summarized The botanical features and seed biology of this species are presented in this review Finally information on the control measures such as mechanical, cultural, chemical and biological methods is discussed.
\end{abstract}

\section{INTRODUCTION}

Tea, rubber and coconut are the most important and widely distributed plantation crops in Sri Lanka. Coconut (Cocos nucifera L.) is the most widespread smaltholder crop. The growth habit of the palm and its canopy structure requires a wide spacing between trees which permits abundant sunlight to reach the understory vegetation. As a result, the unutilized space beneath the plantation becomes invaded by a wide range of perennial and annual weed species. Management of the understory weed growth is therefore considered an essential step in maintaining the plantation. The density and vigour of weeds and their distribution depends largely on the age of the plantation, its agroecological zones and size of the holding.

Among the weedy shrubs, Chromolaena odorata is one of the most troublesome species theat dominates the understory in young coconut plantations. It is not a native weed species of Sri Lanka, but its spread into cultivated areas poses a serious economic problern as it is propagated by both seed and vegetative means resulting in rapid colonization of the understory areas.

\section{History and geographical distribution of Chromolaena odorata}

C. odorat is native to, the Caribbean islands, Central and South America. For many years it was widely known as Eupatorium odoratum L. but was transferred to the resurrected genus Chromolaena by King and Robinson (1970). The accepted view has been that $\underline{C}$. odorata was first transported to the old world via ballast in ships from the West Indies, appearing in Singapore and Malaysia in the 1920's CBennett and Rao, 1968). It was certainly recorded as a major weed in Bengal, Java and Sumatra by 1940 (Laan, 1940). It was reported as a dangerous weed in Sri Lanka in 1944 (Grierson, 1980).

Once established in the Bengal, lower Burma and Malaysia, C. odorata spread rapidly throughout South Asia. Much of this spread must have been natural progressive as the light wind-borne seeds were blown into new areas. By the late 1960s C. odorata was a major weed in Nigeria and since then, it has spread to Ghana, Ivory Coast and Cameroon.

Poddysinghomarang, the common name in Sri Lanka for C. odorata, is a perennial dicotyleclonous weed of the family Asteraceae (Compositae).

\footnotetext{
${ }^{1}$ Coconut Research Institute, Lunuwila, Sri Lanka
} 
C. odorata is a vigorously growing perennial plant with a life span of more than three years. It flowers during the first week of December. The species is known by other common names in different countries: Christmas bush (Triniclad), Siam weed (Malaysia and Indonesia), Communist weed (Vietnam) Saab sua (Thailand), Kalbun or Camphur grass (Burma), Banrnara (Nepal) and Ha-onorny (Philippines) (Muniappan and Marutani, 1988).

\section{Economic Importance}

C. odorata. is considered one of the top three weeds in coconut plantations in Sri Lanka. In Asia it is a problem in coconut, rubber, oilpalm, tea, coffee, cashew, mango, rambutan, teak and other plantations of perennial crops, pasture, forests and vacant lands. In the Pacific, it is a weed of pasture, road sides and vacant lands. According to Holm, et al. (1977) C. odorata is a weed of 13 crops in 23 countries. In the Philippines some villages have become deserted because of non-productivity of the land infested with this weed (Pancho and Plucknett, 1977). It is also poisonous to livestock.

C. odorata is known to harbour a number of insects and mites injurious to crops in Asia. e.g. Aphis gossypiji, Haplothrips gowdeyi (Naezer and Meer Mohr, 1953, Bennett, and Rao, 1968; Joy, Lyla and Abraham, 1979, Ramai and Haq, 1983; and Muniappan and Viraktamath, 1986). In Thailand it has been reported as an alternate host of the leaf fungus, Cercospor spp. (Puckdeedindan, 1966).

In Cambodia, C. odorata is used as a green manure crop for black pepper (Garry, 1963), rice and cassava (Litzenberger and Lip, 1961).

\section{Habitat}

The distribution of $\mathrm{C}$. odorata is limited to warm and humid tropical regions. It is well established by ecologists that there is commonly a close correlation between the distribution of vegetation and two major features of climate namely temperature and precipitation (Woodward and Williams, 1987). The geographical distribution of $\mathrm{C}$. odorata seems limited to areas where the rainfall is $200 \mathrm{~cm}$ and above per annum and the temperature range is between $20-37^{\circ} \mathrm{C}$. It is distributed in areas up to about $1000 \mathrm{~m}$ in altitude close to the equator.

C. odorata cannot tolerate heavy shading, as a result it does not penetrate thick undisturbed native forest vegetation. In the disturbed forest areas and in plantations of coconut, rubber, cashew, oil palm, citrus, coffee, tea, mango, rambutan and other perennial crops, pasture and vacant lands, it becomes very well established and better growth performance than open condition in partially shaded conditions (Gunasekara, 1993) and so becomes a serious weed.

\section{Botanical features of $\underline{\mathrm{C} \text {. odorata }}$}

C. odorata is a perennial herb. Under favourable weather conditions, the plant can grow upto $25 \mathrm{~cm}$ in height in a week and in six months can form an almost impenetrable shrub 2-4m high. The whole plant is hairy and glandular and emits a pungent odour when crushed (Sheldrick, 1968). On good open land Chromolaena forms much branched stems. The stems are woody and may be up to 5 $\mathrm{cm}$ in diameter at ground level. In shade it develops a more etiolated form and becomes a partial creeper on trees. Stems will grow up to $3 \mathrm{~m}$ high, with large leaves and long slender internodes twisted among the branches of trees (Cruttwell, 1968). Leaves are opposite, triangular to elliptical with a serrated edge (Fig. 1.2). The lenght of a leaf is about 4-10 cm (Gooding, Loveless and Proctor, 1965) or 5-15 cm (Britton and Millspaugh, 1962) and leaf width is about $1-5 \mathrm{~cm}$. The youngest pair of leaves of a vegetative shoot have a characteristic purple pigmentation towards their bases (Sheldrick, 1968). The petiole is about 1-4 cm Iong (Britton and Millspaugh, 1962). 
Flowering takes place in December. Sajise, Palis, Norcio and Lales (1974) reported that the flowering response of Chromolaena to varying photo periods indicated that it can flower over a range of daylenght conditions (10-14 hrs), but flowering was greatly enhanced by, shorter daylenghts (10 hours). The infloresence is laxly to densely corymbose, the heads are terminal and cylindrical being $4-5 \mathrm{~mm}$ across and $8-12 \mathrm{~mm}$ Iong. The branches bearing the corymbs often form a large pannicle like structures (Fig. 1.2). The involucre is cylindrical, and bears several series of bracks, which are oblong, bluish or straw coloured. The outer series being shorter than the inner, which are about $9 \mathrm{~mm}$ in lenght. No ray florets are borne in the flower heads, which bear 10-20 florets; the corolla is pale lavender or white and about $5 \mathrm{~mm}$ long. Achenes are $4-5 \mathrm{~mm}$ long, somewhat hairy or glabrous; the pappus is whitish and 4-5mm long (Britton and Millspaugh), 1962; Gooding, Loveless an Proctor, 1965).

After flowering there is a regrowth of new shoots from an axils of all old leaves. During the dry season, if it is severe, all the old leaves may dry up and regrowth may be delayed till the onset of the rains. In most years, there is some growth throughout the year, though in very dry periods, this may be slight. With the rains for some time in the middle of the year, there is a spurt of growth with new shoots coming from ground level. Many stems and parts of the stem die after flowering, so that an old bush of Chromolaen is a tangled mass of old and new stems, long and short and much branched (Cruttwell, 1968).

\section{Seed biology}

The main medium of seed dissernination is the wind. $\mathrm{C}$. Odorata has an arnazing ability to produce vast amounts of seeds. Seed production has been estimated at about 80,000 - 90,000 seeds/plant (Weerakon, 1972). The seeds are ideally formed for this purpose. They are produced in great numbers, are light and bear a pappus. Normally 100 seed weight is about $20 \mathrm{mg}$ (Gunasekara, unpublished data). After the seeds fall to the ground, if the necessary conditions are available, all the seeds which are viable will germinate within a short period as they do not have dormancy (Weerakon, 1972). Erasmus and Van Staden (1987) reported that the percentage germination of achenes of $\mathrm{C}$. Odorata stored dry in the dark at $25^{\circ} \mathrm{C}$ for seven months was markedly higher than that of freshly harvested achenes (seeds). This is indicative of an after ripening requirement that may be of benefit to the species by ensuring temporal distribution of germination. Germination of freshly harvested achenes from various sites differed. However, after 7 months of dry, dark storage at $25^{\circ} \mathrm{C}$ no differences were present, thus confirming the after ripening requirement (Erasmus and Van Staden, 1987). When the seeds are on the surface of the soil, they germinate immediately. but seeds that get buried at a depth of $0.5 \mathrm{~cm}$ or more do not germinate (Weerakon, 1972). Temperature is an important environmental factor for seed germination of Chromolaena. The optimal temperature for germination is $15-30^{\circ} \mathrm{C}$ (Erasmus and Van Staden, 1986). Light is essential for seed germination. Newly collected seeds show a greater percentage of germination when exposed to sunlight (NVeerakon, 1972). According to the experiments carried out by Erasmus and Van Staden (1986) the promotive effect of red light on the germination of Chromolaena achenes can be reversed by subsequent exposure to farred light. This is typical of a phytochrome mediated germinated response.

\section{Control of Chromolaena odorata}

Manual slashing and use of motorized bushcutters and tractor drawn equipment ate commonly used for clearing $\underline{C}$. odorata. Okioye (1977) found that slashing caused rapid regeneration but rcpeated slashing eventually caused the death of weeds. Manual weeding is mostly done in places where cheap and plentiful labour is available. Use of motorized bushcutters and tractor drawn equipment is also limited because of the restricted accessibility of areas where this weed grows (Erasmus, 1988). Slashing and burning are carried out in some places. The top portions of C. odorata 
bum readily during the dry seasons, while the bases of plants are resistant to fire. Seeds also germinate well after a fire (Liggitt, 1983).

\section{b) Cultural control}

Cover crops such as Pueraria javanica, Pueraria phaseoloides, Calapagonium caeruleum and Desmodium ovalifolium have been used to suppress of $\mathrm{C}$. odorata and found to be ineffective (Ambika and Jayachandra, 1990). However, Salgado (1972) reported that Tephrosia purpurea grown as a cover crop in coconut plantations was ineffective in suppressing C. odorata in Sri Lanka.

\section{c) Chemical control}

In India Nair (1973) reported that Gramoxone at $0.3 \%$ concentration was not effective in controlling this weed. However, Rai (1976) found that Gramoxone in combination with 2-4D sodium salt was effective. Mathew, Punnoose and Potty, (1977) reported that a combination of 1.5 litres of Gramoxone and $0.75 \mathrm{~kg}$ Fernonoxone gave good control of this weed. Tumaliuan and Halos (1979) also reported that Gramoxone was effective in controlling Chromolaena in the Philippines. In Indonesia, Soerjani, Soedarsan, Mangoensoekarjo, Kuntohartono and Sundaru (1975) found that Picloram was also effective in its control of Chromolaena. Madrid (1974) reported that Picloram at 1 $\mathrm{kg} / \mathrm{ha}$ and Dicamba at $2 \mathrm{~kg} / \mathrm{ha}$ were the recommended rates to control the weed.

Erasmus (1988) and Liggitt (1983) reviewed chemical control of C. odorata in South Africa. In general, the timing of herbicide application was important in its control. Plants were most susceptible when herbicides were applied at the young seedling stage or to the regrowth after slashing.

\section{d) Biological control}

Several insects and mites feed on Choromolaena (Crutwell, 1974) and this has led to biological control measures being introduced. Pareuchaetes pseudoinsulata Rego Barros (Lepidoptera Arctiidae) was introduced to Ghana, Nigeria, India, Sri Lanka and Sabah (Malaysia) by the Commonwealth Institute of Biological Control (CIBC) in the early 1970's to attack Chromolaena (Julian, 1987). The insect was successful in Sri Lanka. The seed feeding weevil, Apion brunneonigrum Beguin- Billecoq Coleoptera: Curuloinidae) has been released in India, Sabah, Sri Lanka, Ghana, Nigeria (Julian, 1987). No recoveries of this weevil have been made in these countries. Acalitus adoratus Keifer (Acarinae: Eriophydae) has been identified as one of the natural

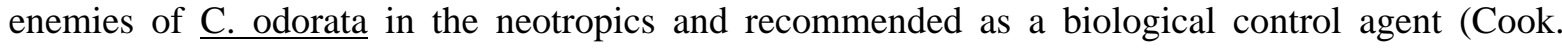
1984).

\section{ACKNOWLEDGEMENTS}

I thank Dr. M. de S. Liyanage, Deputy Director (Research) and Acting Director of the Coconut Research Institute for his assistance. The assistance given by Dr. D.N.S. Fernando, Dr. C. Jayasekara, Miss S. Ranasinghe and Mr. A. Nainanayake is also acknowledged. 


\section{REFERENCES}

AMBIKA, S. R. and JAYACHANDRA (1980) Suppression of plan tation crops by Eupatorium weed. Current Science, 49. 874-875.

BENNETT, F. D. and RAO, V. P. (1968) Distribution of an introduced week Eupatorium odoratum in Asia and Africa and possibility of its biological control, PANS 14, 277-281

BRITTON, N.L. and MILLPAUGH, C.F. (1962) The baharna Flora. The New York Botanical Garden, 438.

COCK, M. J. W. (1984): Possibilities for biological control of Chromolaena odorata. Tropical Pest Management, $\underline{30,}, 7-13$

CRUTFWELL, R. E. (1968) Preliminary survey of potential biological control agents of Eupatorium in Trinidad. Proceedings of 9th British Weed Control Conference. p. 836-841

ERASMUS, D.J. (1988) A review of mechanical and chernical control of Chromolaena odorata, in South Africa. Proceedings of the First International Workshop on Biological Control of $\underline{C}$. odorata. Feb.29 - March 4, 1988, Bangkok, Thailand. 37-39

ERASMUS, D. J. and VAN STADEN, J. (1986) Germination of Chromolaena odorata (L.) K. \& R. achenes: effect of temperature and light. Weed Research, 26 75-81

ERASMUS, D. J. and VAN STADEN, J. (1986) Germination of Chromolaena odorata (L.) K. \& R. achenes: effect of storage, harvest, locality and the pericarp. Weed Research, 27, 113-118.

GARRY, R. (1963) The changing fortunes and future of pepper growing in Cambodia. Journal of Tropical Geography,.L7, 133-142

GRIERSON, A. J. C. (1980) Compositae in Flora of Ceylon. Smithsonian Institute, USA, P 1

GOODING, E. C. B., LOVESS, A. R. and PROCTOR, G. R. (1965) Flora of Barbados. H.M. Stationary office, London

HOLM, L. G., PLUCKNETT, D. L., PANCHO, J. V. and HERBERGER, J. P. (1977). The world's worst weeds. University Press of Hawaii, Honolulu, Hawaii.

JOY, P. J., LYLA, K.R. and ABRAHAM, C.C. (1979) Preliminary studies on the aphid pests of Eupatorium odoratum an important weed in plantations of Kerala. Proceeding of Second Annual Symposium of Plantation Crops, Ooty. 272275.

JULIAN, M.H. (1987) Biological control of weeds: A world catalogue of agents and their target weeds. Commonwealth Agricultural Bureaux International, Wallingford.

KING, R. and ROBINSON, H. (1970): Chromolaena. Phytologia, 20, P. 244

LANN, P.A. (1940) Motschildluis en Eupatorium als oorzaken van pseudomozaiek. Vluqsehr. Deli. Proefst. Medau. 67. 4-6.

LITZENBERGER, S. and LIP, H.T. (1961): Utilization Etipatorium odoratum L. to improve crop yields in Carnhodia. Agronomy Journal, 53, 321 -324. 
MATHEW, M., PUNNOOSE, K.I. and POTTY, S. N. (1977) Report on the results of chemical weed control experiments in the rubber plantations in South India. Journal of Rubber Research Institute of Sri Lanka., 54, 478-488

MUNIAPPAN, R. and WIRAKTAMATH, C. A. (1986) Insects and mites associated with Chromolaena odorata. Entomon, 11 285-287.

NAEZER, H. W. and MEER MOHR. (1953) Insects and Eupatorium odoratum. Tropical Nature, Bogor, Indonesia, $\underline{33,59-60}$

NAIR, P. N. (1973) The effect of gramoxone application on Eupatorium odoratum. Indian Forester. 99 $43-48$

OLAOYE, S. O. A. (1977) The effect of slashing on the performance of Eupatorium odoratum in Nigeria. Proceedings of 7th Nigerian Weed Science Society Conference.

PANCHO, J. V. and PLUCKNETT, D. L. (1977) Chromolaena odorat. R.M. King and H.R. Robinson. A new record of a noxious weed in the Philippines. Philippine Journal of Animal Science, 8 143-149.

PUCKDEEDINDAN, P. (1966) A supplementary host list of plant diseases in Thailand. Technical Bulletin, Department of Agriculture, Bangkok.

RAI, S.N. (1976) Eupatorium and weedicides. Indian Forester, 102, 449-454.

RAMANI, N. and HAQ, M.A. (1983) Oribatid mites (Acari) associated with Eupatorium odoratum. Indian Coconut Jour nal of Acarology, 8 95-99.

SAISE, P.E., R.K. NORCIO, N.V. and LALES, J.S. (1974) The biology of Chromolaena oclorata. (L.) K. \& R. 1. Flowering behavior, pattern of growth and nitrate metabolism. Philippine Weed Science Bulletin, 1 17-34.

SALGADO, M.L.M. (1972) Teprosia purpure (Pila) for the control of Eupatorium and as a green manure on coconut estates. Ceylon Coconut Planters Review 6 160-174.

SHELDRICK, R. D. (1968) The control of Siam weed (Eupatorium odoratum L.). Joumal of Nigerian Institute of Oil Palm Research, 5, 4-19.

SOERJANI, M., SOEDARSAN, A., MANGOENSOEKARJO, S., KUNTOHARTONO, T. and SUNDARU, M. (1975). Weed Problems and Prospects for Chemical control in Indonesia. 5th Conference of the Asian Weed Science Society.

TUMALIUAN, B. T. and HALOS, S. C. (1979). Screening herbicidal preparations and mixtures for clearing reforestation areas. Sylvatrop Philippines Forest Research Journal, 4 151-159.

WEERAKON, W.L. (1972) Studies on biology and control. of Eupatorium odoratum. M. Sc. thesis, University of Sri Jayawardenapura, Sri Lanka.

WOODWARD, F. 1. and WILLIAMS, B. G. (1987). Climate and plant distribution of global and local scales. Vegetatio, 69, 189-197. 